\title{
Tissue Guanosine-3',5'-Cyclic Monophosphate Levels and Soluble Guanylate Cyclase Activity
}

\section{A POSITIVE CORRELATION DURING UNILATERAL CRYPTORCHIDISM}

\author{
IN THE RAT TESTIS
}

\author{
W. Austin Spruill, Alton L. Steiner, and H. Shelton Earp, Departments of \\ Medicine and Pharmacology, University of North Carolina, Chapel Hill, \\ North Carolina 27514
}

A B S TRACT The relationship between the subcellular distribution of guanylate cyclase and tissue guanosine-3',5'-cyclic monophosphate (cGMP) levels was investigated in rat testes after surgically induced unilateral cryptorchidism. Placement of one of a testis pair in the abdominal cavity results in loss of testicular weight and function in the abdominal testis whereas the remaining scrotal testis appears to be functionally normal. Within 5 days after surgery, tissue cGMP levels were increased by twofold in the abdominal testis. A fourfold elevation was noted from 10 to 30 days after surgery. Whereas the homogenate guanylate cyclase activity was only slightly elevated 10 and 20 days postoperatively, a $200 \%$ increase in the soluble guanylate cyclase activity was seen at 5 days. Between 10 and 30 days, the rise in activity was $>250 \%$ ( $P$ $<0.01$ ). An increase in soluble guanylate cyclase activity was noted when the data were expressed as per milligram protein, per milligram DNA or per whole testis. Conversely, particulate guanylate cyclase activity was reduced by $40 \%$ in the cryptorchid testis. Kinetic analysis of the soluble enzyme prepared from abdominal and scrotal testes yielded linear Lineweaver-Burke plots for both enzyme preparations with an identical $K_{m}$ for guanosine triphosphate, but a threefold higher maximal velocity for the abdominal enzyme. When the soluble guanylate cyclases from both testes were mixed and assayed together, the activities were additive rather than exhibiting synergism or inhibition. These experiments indicate that the

This work was presented in part at the Federation of American Societies for Experimental Biology meeting, April 1977, Chicago, Ill.

Received for publication 25 July 1977 and in revised form 21 April 1978. altered $V_{\max }$ is not due to a transferable activator or inhibitor.

An immunocytochemical technique was used to assess the cell type in which the alterations in cGMP metabolism occurred. Comparison of the scrotal and abdominal testes revealed that the abdominal testis exhibited enhanced cGMP immunofluorescence within the cells lining the inner aspect of the seminiferous tubule as well as tubular elements and interstitial cells. Thus, it is inferred that the correlated changes in soluble guanylate cyclase activity and cGMP levels occur in several of the cell types that remain viable within the cryptorchid testis.

\section{INTRODUCTION}

The precise role of guanosine-3', $5^{\prime}$-cyclic monophosphate (cGMP) ${ }^{1}$ in biologic regulation is unknown, but an expanding and sometimes controversial literature has implicated this cyclic nucleotide in the control of diverse cellular functions (1), e.g., growth $(2,3)$, and development $(4,5)$. To obtain insight into the biologic role of cGMP, investigators have studied the regulation of the components of cGMP metabolism. This approach encompasses research on guanylate cyclase, the enzyme which catalyzes the formation of cGMP from guanosine triphosphate (GTP). There are two major forms of guanylate cyclase, soluble and particulate. These can be separated by ultracentrifugation and once separated, exhibited distinct properties $(6,7)$. The ratio of the soluble to particulate activity varies from tissue to tissue, as does the resting tissue cGMP concentration $(8,9)$. However, the relationship be-

\footnotetext{
${ }^{1}$ Abbreviations used in this paper: GMP, guanosine- $3^{\prime}, 5^{\prime}-$ monophosphate; GTP, guanosine triphosphate; Ig, immunoglobulin; LDH, lactic dehydrogenase.
} 
tween the activity of the two forms of guanylate cyclase measured in vitro and the tissue concentration of cGMP remains to be fully elucidated. This has been a difficult problem to approach because unlike the well-studied adenylate cyclase, the guanylate cyclases do not, in most instances, respond in vitro to the biologic stimuli which raise cGMP levels (10). Rather, there is good evidence that acute changes in guanylate cyclase activity are mediated by the local concentrations of divalent cations, adenine nucleotides, and fatty acids (10-13). In addition, the oxidation-reduction state of the tissue may be important in regulating activity (14). Another control mechanism may exist which governs the production of cGMP, i.e., the regulation of the total cellular content of soluble and particulate guanylate cyclase. The present report addresses this latter type of regulation; specifically, two questions were asked: $(a)$ Does the partitioning of enzyme into the soluble and particulate fraction bear a relationship to the tissue content of cGMP? and $(b)$ Can the two forms be regulated independently?

In these experiments, unilateral cryptorchidism was used as a model for examining cGMP metabolism during testicular atrophy. A sustained elevation in tissue cGMP, with a parallel increase in soluble guanylate cyclase activity, was observed in the abdominal testis. Thus, in the rat testis the tissue concentration of cGMP correlates best with the activity of the soluble guanylate cyclase. Additionally, when contrasted with the increase in particulate guanylate cyclase observed during rat liver regeneration $(3,4,15)$, the present data emphasize the potential for independent regulation of the two forms of guanylate cyclase.

\section{METHODS}

Male Sprague-Dawley rats (Charles River Breeding Laboratories, Inc., Wilmington, Mass.) were rendered unilaterally cryptorchid under ether anesthesia at 20 or 60 days of age. A small incision was made in the abdomen and one testis was gently forced into the abdominal cavity. A suture through the tunica albuginea and the abdominal wall was sufficient to secure the testis in the abdominal cavity. The remaining scrotal testis was used as a control for the abdominal testis in all experiments because comparison of the scrotal testes from unilaterally cryptorchid rats with testes from agematched control rats revealed them to be indistinguishable with regard to cGMP levels and guanylate cyclase activities.

Radioimmunoassay of cG.MP. At specific times after surgery rats were sacrificed by cervical dislocation, and samples of testicular tissue $(50-200 \mathrm{mg}$ ) were removed and frozen immediately in liquid nitrogen. Frozen tissues were weighed and homogenized in $1 \mathrm{ml}$ of $6 \%$ trichloroacetic acid (TCA). After centrifugation at $2,400 \mathrm{rpm}$ for $20 \mathrm{~min}$, a $750-\mu \mathrm{l}$ portion of the supernate was aspirated and washed three times with 10 vol of diethyl ether. Samples were dried under nitrogen at $60^{\circ} \mathrm{C}$. Dried samples were reconstituted in $1 \mathrm{ml}$ of a
0.05-M sodium acetate buffer, pH 6.2. Cyclic GMP was determined by radioimmunoassay according to Steiner et al. (16). Specificity of the radioimmunoassay for testicular cGMP has been described (5).

Guanylate cyclase assay. Fresh tissue samples (100-300 $\mathrm{mg}$ ) obtained from decapsulated testes were homogenized in $20 \mathrm{vol}$ of $0.25 \mathrm{M}$ sucrose, containing $10 \mathrm{mM}$ Tris- $\mathrm{HCl}$ buffer ( $\mathrm{pH} 7.6$ ) at $4^{\circ} \mathrm{C}$, using a Brinkmann Polytron (Brinkmann Instruments, Inc., Westbury, N. Y.) equipped with a PT-10 Probe. Homogenization at a setting of 4 for $20 \mathrm{~s}$ produced complete cellular disruption as determined by light microscopic examination of homogenized samples. Soluble and particulate fractions were separated by centrifugation at $105,000 \mathrm{~g}$ for $60 \mathrm{~min}$. Supernates were decanted, and the pellets were washed and resuspended in the original volume of buffer. Resuspended pellets were then dispersed with the Polytron before assay (setting of 5 for $15 \mathrm{~s}$ ).

Guanylate cyclase activity was determined according to the method of Kimura and Murad (6). 150- $\mu$ l reaction mixtures contained $3 \mathrm{mM} \mathrm{MnCl}, 15 \mathrm{mM}$ phosphocreatine, 20 $\mu \mathrm{g}$ creatine phosphokinase, and $30-100 \mu \mathrm{g}$ of the enzyme preparation. Guanylate cyclase assays were initiated by addition of $1 \mathrm{mM}$ GTP and incubated for $10 \mathrm{~min}$ at $37^{\circ} \mathrm{C}$. Assays were terminated by the addition of $0.9 \mathrm{ml}$ of a $50-\mathrm{mM}$ sodium acetate buffer $\left(\mathrm{pH} \mathrm{4.0)}\right.$ and heated for $2 \mathrm{~min}$ at $90^{\circ} \mathrm{C}$. The cGMP generated was determined by radioimmunoassay. Addition of $0.2 \mathrm{mM}$ mix to the assay mixture was sufficient to allow recovery of $>90 \%$ of exogenously added cGMP. When indicated, the particulate enzyme was treated by incubating this fraction with $1 \%$ Triton X-100 (Rohm \& Haas Co., Philadelphia, Pa.) for $1 \mathrm{~h}$ at $4^{\circ} \mathrm{C}$ before assay. Protein was determined by the method of Lowry et al. (17). DNA determinations were made according to the method of Burton (18). Statistical analysis was performed by the Student's $t$ test for paired observations.

The lactic dehydrogenase activity was determined by the method of Wroblewski et al. (19). The 5-nucleotidase assay was performed using a coupled assay system. The 30 - to 50 $\mu \mathrm{g}$ protein sample was incubated with $0.2 \mathrm{m.M} 5^{\prime}$-AMP, $20 \mathrm{mM}$ Tris ( $\mathrm{pH} 7.2$ ), $5 \mathrm{mM} \mathrm{MgCl}_{2}$, and $5 \mu \mathrm{g}$ of adenosine deaminase. Samples were incubated for $10 \mathrm{~min}$ at $37^{\circ} \mathrm{C}$, and the reaction was terminated by the addition of $5 \%$ TCA. Under these conditions, the conversion of adenosine to inosine was complete and results in an optical density change which was measured in a Gilford spectrophotometer (Gilford Instrument Laboratories Inc., Oberlin, Ohio). The conversion of 5'-AMP to adenosine was calculated by subtracting tissue blanks incubated without adenosine deaminase or without 5'-A.MP.

Immunocytochemical studies. Antiserum to cGMP was raised in rabbits by repeated injections of 2'-0-succinyl cyclic GMP conjugated to keyhole limpet hemocyanin. The immunoglobulin fraction (Ig) of these antisera, having high specific titers, were used as the primary immunoreagent in the localization of cG.MP. The antiserum was placed on air-dried cryostat sections of unfixed frozen tissues. After a 30-min incubation in a moist chamber at room temperature, sections were washed for $3 \mathrm{~min}$ in phosphate-buffered saline at $\mathrm{pH}$ 7.2. Washings were repeated three times. The bound rabbit IgG was then localized by exposure of the sections to fluorescein isothiocyanate-conjugated goat IgG, raised against rabbit IgG. Sections were again incubated for $30 \mathrm{~min}$ followed by repeated rinsings in phosphate-buffered saline. A $50 \%$ phosphate-buffered saline-glycerin solution was applied over the section, and coverslips were placed on the slides. Slides were examined by dark field fluorescence microscopy with incident illumination using $480-$ to $510-\mu \mathrm{m}$ barrier filters. 
No significant staining was observed when the Ig fraction from nonimmunized rabbits was used as the primary immunoreagent. No staining was observed if the fluoresceinlabeled goat-anti-rabbit IgG fraction was reacted with the sections without prior exposure to the rabbit anti-cGMP antibody. The cGMP staining pattern could be competitively inhibited with $50 \mu \mathrm{M}$ cGMP. A complete review of the specificity of this technique has recently been published (20).

\section{RESULTS}

Surgically induced unilateral cryptorchidism results in a time-dependent loss of testicular weight, germinal cells, spermatogenic capacity and Sertoli's cell function $(21,22)$. Fig. 1 shows the effect of cryptorchidism on cGMP metabolism. A twofold rise in tissue cGMP levels occurs within 5 days. A four- to sixfold increase in cGMP persists for at least 30 days. Homogenate, soluble, and particulate guanylate cyclase activity was also measured in abdominal and scrotal testis pairs. Homogenate guanylate cyclase activity in the abdominal testis was slightly increased 10-20 days after surgery (Fig. 1). A more meaningful comparison of the changes in activity of guanylate cyclase was seen when the soluble and particulate forms were separated by ultracentrifugation. The soluble activity in the abdominal testis doubled 5 days after surgery. A $250 \%$ rise observed 10-20 days postoperatively progressed to a $280 \%$ elevation at 30 days. The rise in specific activity at 10 days is equivalent when expressed per milligram protein or per milligram DNA (data not shown). To show that an absolute rise in soluble activity occurred, the data were expressed as soluble guanylate cyclase activity per whole testis. By 10 days, a 55\% reduction in tissue weight was observed, but an absolute increase in soluble guanylate cyclase activity was seen in the abdominal testis $(0.86 \pm 0.06$ vs. $0.73 \pm 0.09 \mathrm{~nm}$ cGMP/testis per $\min , n=10$, $P<0.05)$. When the particulate activity in the abdominal testis was examined, a significant decrease was seen at all time points studied. Thus, the increase in tissue cGMP levels in the abdominal testis was paralleled by a significant rise in soluble guanylate cyclase activity.

The testis is a heterogenous tissue, and unilateral cryptorchidism results in a selective loss of specific germinal elements within the seminiferous tubules. To detect whether the loss of mature germinal elements was the sole determinent of the observed changes, the experiments were repeated in 20-day-old rats. At this
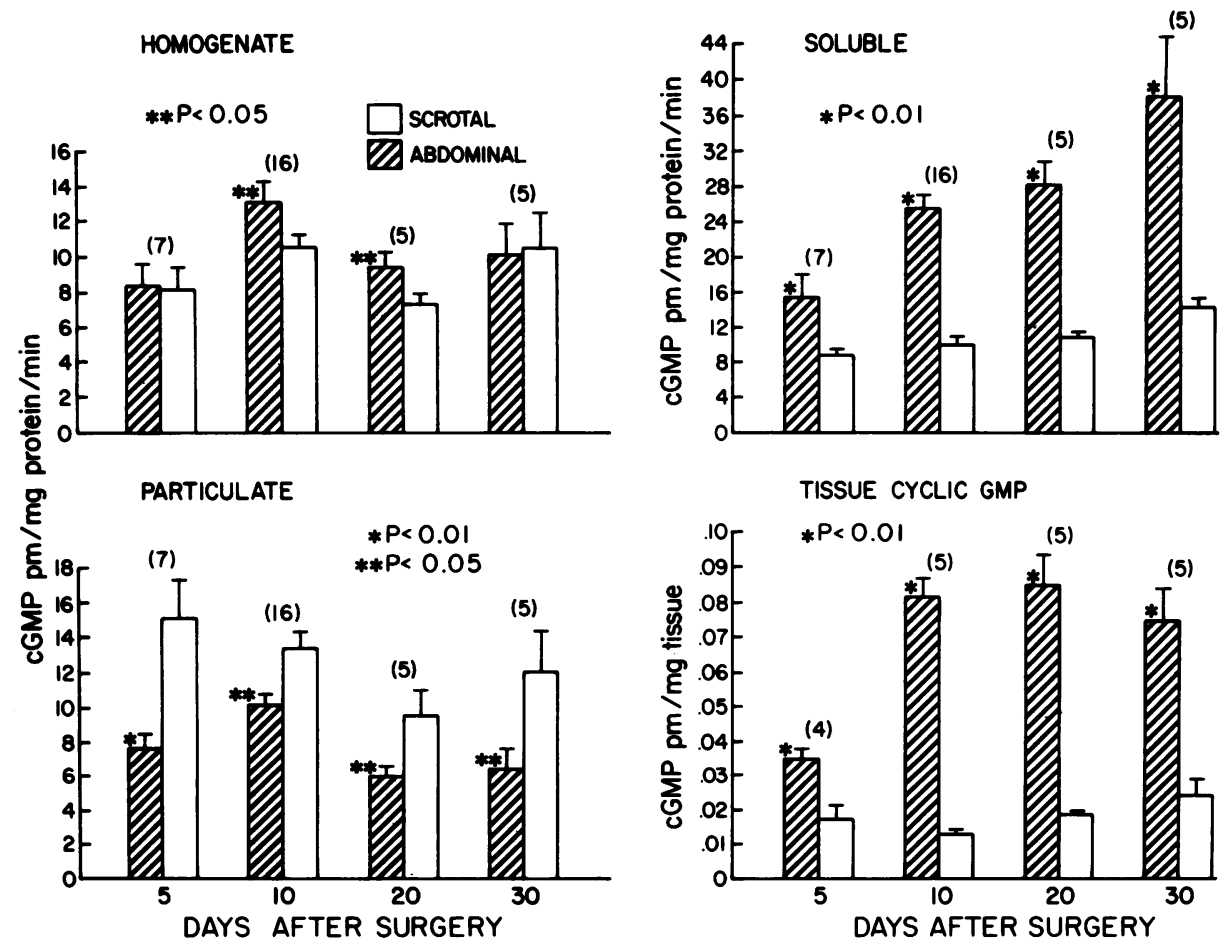

FIGURE 1 Testicular guanylate cyclase activity and tissue cGMP concentration at various times after surgically induced unilateral cryptorchidism in adult rats. Guanylate cyclase activities and tissue cGMP concentrations were determined as described in Methods. Bars represent the mean of the activities, or levels, and vertical lines, the SEM. The number of determinations is shown in parentheses. Asterisks denote significant differences between activities or levels in abdominal and scrotal testes. 
age spermatogenesis has only advanced into the first meiotic division, and thus, the testis is virtually free of mature germinal elements (23). Unilateral cryptorchidism produced a mean weight reduction of $35 \%$ in the abdominal testis 10 days postoperatively. The soluble guanylate cyclase activity was increased by $250 \%$, and the particulate guanylate cyclase activity was reduced by $40 \%$ (Table I). Whereas differences in the hormonal milieu between the 20- and 60-dayold rats exists, this model provides the opportunity to study the effect of the abdominal location on testes in the absence of mature germ cells. The results indicate that the observed changes do not simply reflect the loss of mature germinal elements in the cryptorchid testis of the 60-day-old rats.

Additional experiments were performed in an attempt to indirectly determine if the increase in soluble guanylate cyclase activity, observed in the abdominal testis, was due to an increase in the number of enzyme molecules or an increase in the activity of preexisting enzyme. Fig. 2 shows the kinetic analysis of the soluble guanylate cyclase obtained from an abdominal and scrotal testis pair. The double reciprocal plot reveals that the two preparations have an identical $K_{m}(60 \mu \mathrm{M})$ for GTP, but the $V_{\max }$ for the abdominal soluble guanylate cyclase is threefold higher. These findings could be explained by the induction of enzyme, the appearance of an activator, or the loss of a noncompetitive inhibitor of soluble guanylate cyclase. The latter two possibilities were approached by mixing experiments in which the activities of soluble guanylate cyclase from abdominal and scrotal testes were assessed separately and after the samples were mixed together. Table II shows that mixing the guanylate cyclases from the abdominal and scrotal testes results in a completely additive activity. These results mediate against the presence of either a transferable activator in the abdominal testis or a noncompetitive inhibitor in the scrotal testis.

TABLE I

Effect of Unilateral Cryptorchidism on Testicular Guanylate Cyclase Activity in 20-day-old Rats

\begin{tabular}{ccc}
\hline & \multicolumn{2}{c}{ Cyclic GMP formed } \\
\cline { 2 - 3 } $\begin{array}{c}\text { Subcellular } \\
\text { fraction }\end{array}$ & $\begin{array}{c}\text { Scrotal } \\
\text { testis }\end{array}$ & $\begin{array}{c}\text { Abdominal } \\
\text { testis }\end{array}$ \\
\hline
\end{tabular}

pmol/mg protein/min

$\begin{array}{llr}\text { Soluble } & 11.83 \pm 1.44 & 28.63 \pm 1.87^{*} \\ \text { Particulate } & 12.50 \pm 1.51 & 7.29 \pm 1.72^{*}\end{array}$

Rats were rendered unilaterally cryptorchid at 20 days of age and sacrificed 10 days later. Values represent mean \pm SEM of six rats.

* Values that are significantly different $(P<0.01)$ from the values in the scrotal testis.

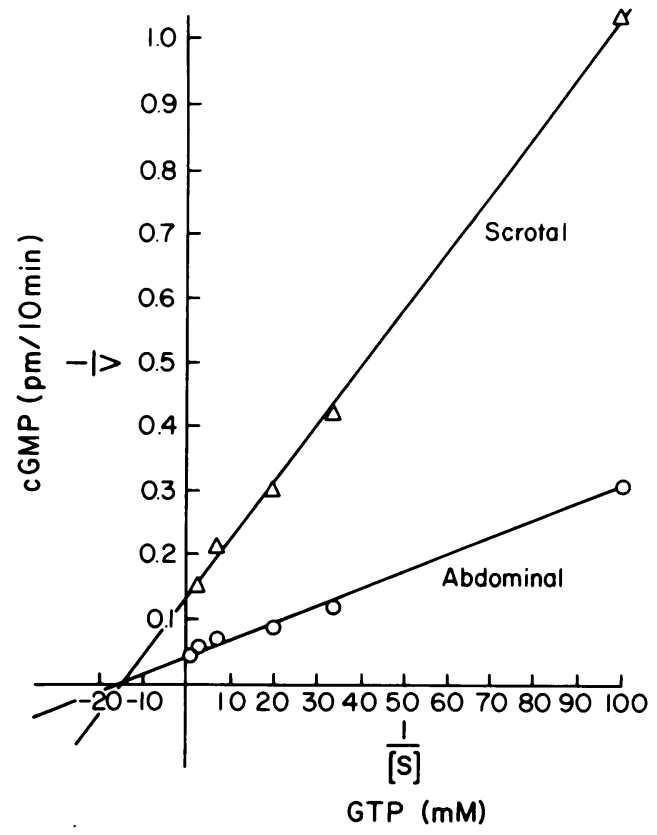

FIGURE 2 Double reciprocal plot of cyclic GMP formation as a function of the GTP concentration. The activity of the soluble guanylate cyclase from abdominal and scrotal testis (48 $\mu \mathrm{g}$ of protein for each) was determined in the presence of $3 \mathrm{mM} \mathrm{MnCl}$ and varying concentrations of GTP. Each point represents the mean of triplicate assays.

The soluble guanylate cyclase from most tissues can be activated in vitro by $\mathrm{Ca}^{++}$if the assay is performed at suboptimal $\mathrm{Mn}^{++}$concentrations $(6,7)$. If the change in soluble guanylate cyclase activity observed in the abdominal testis was due to an increase in enzyme molecules rather than an activation of preexisting enzyme, then the calcium stimulation of the soluble guanylate cyclase from both the abdominal and scrotal testes should be proportional. When soluble guanylate cyclase, from either the abdominal or scrotal testis, was incubated with $1 \mathrm{mM}$ suboptimal $\mathrm{Mn}^{++}$only $50 \%$ of the optimal activity $\left(3 \mathrm{mM} \mathrm{Mn} \mathrm{Mn}^{++}\right)$was ex-

TABLE II

Soluble Guanylate Cyclase Activity in Testis from Unilaterally Cryptorchid Rats

\begin{tabular}{lc}
\hline \multicolumn{1}{c}{ Enzyme source } & Cyclic GMP formed \\
\hline & pmol/10 min \\
Scrotal & $4.42 \pm 0.43$ \\
Abdominal & $9.24 \pm 0.80$ \\
Abdominal and scrotal & $13.93 \pm 0.68$ \\
\hline
\end{tabular}

Rats were rendered unilaterally cryptorchid at 60 days of age and sacrificed 10 days later. For each rat, soluble guanylate activity was determined in abdominal and scrotal testis alone and after mixing the samples together. Values represent the mean $\pm S E M$ of six experiments. 
TABLE III

Effect of Triton X-100 on Particulate Guanylate Cyclase from Testis of Unilaterally Cryptorchid Rats

\begin{tabular}{|c|c|c|c|}
\hline \multirow{2}{*}{$\begin{array}{l}\text { Enzyme } \\
\text { source }\end{array}$} & \multicolumn{2}{|c|}{ Cyclic GMP formed } & \multirow{2}{*}{$\begin{array}{c}\text { Ratio of } \\
\text { (+Triton/-Triton) }\end{array}$} \\
\hline & -Triton & + Triton & \\
\hline \multicolumn{4}{|c|}{ pmol/mg protein/min } \\
\hline Abdominal & $11.91 \pm 1.57$ & $82.85 \pm 4.38$ & 6.96 \\
\hline Scrotal & $18.27 \pm 1.27$ & $112.62 \pm 9.21$ & 6.16 \\
\hline
\end{tabular}

Rats were rendered unilaterally cryptorchid at 60 days of age and sacrificed 10 days later. The particulate fraction was prepared and incubated with $1 \%$ Triton X-100 for $60 \mathrm{~min}$ at $4^{\circ} \mathrm{C}$ before assay. Values represent mean \pm SEM of six rats.

pressed. When $3 \mathrm{mM} \mathrm{Ca}^{++}$is then added the activity from either testis was doubled.

The possibility exists that the rise in soluble guanylate cyclase activity in the abdominal testis was caused by a translocation of particulate guanylate cyclase to the supernate during the preparation of the guanylate cyclase. This is unlikely due to the following observations. The soluble guanylate cyclase from the abdominal testis exhibits classical Michaelis-Menten kinetics (Fig. 2). These kinetic properties have been reported for soluble guanylate cyclases from other tissues $(6,7)$. In contrast, in the testes, ${ }^{2}$ as well as other tissues, kinetic analysis of particulate guanylate cyclase solubilized with detergents yields nonlinear Lineweaver-Burke plots $(6,7)$. If the threefold increase in activity (Fig. 1) and $V_{\max }$ (Fig. 2) of the abdominal testis soluble guanylate cyclase was due to the translocation of particulate guanylate, one would expect to find the curvilinear kinetic pattern characteristic of the particulate enzyme when the abdominal testissoluble enzyme was examined. This was not observed. Additionally, solubilization of the particulate guanylate cyclase with $1 \%$ Triton $\mathrm{X}-100\left(4^{\circ} \mathrm{C}\right.$ for $\left.1 \mathrm{~h}\right)$ greatly increases the activity of the enzyme $(6,7)$. When abdominal and scrotal particulate fractions were treated in this manner, both preparations underwent a sixfold increase in activity (Table III). The similar response to detergent treatment in both the abdominal and scrotal particulate preparations suggests that relationship of the enzyme to membrane components is unchanged by cryptorchidism.

Alteration in other enzyme activities have been previously reported during unilateral cryptorchidism (24). To compare the changes observed in the subcellular distribution of guanylate cyclase with other soluble and particulate enzymes, the activity of a soluble enzyme, lactic dehydrogenase (LDH), and a particulate enzyme,

\footnotetext{
${ }^{2}$ Spruill, W. A., A. L. Steiner, and H. S. Earp. Unpublished results.
}

5 '-nucleotidase was assessed (Table IV). LDH activity was elevated $180 \%$ in the abdominal testis 10 days after surgical cryptorchidism. The change in LDH activity was in the same direction as soluble guanylate cyclase activity, but the increase was only $50 \%$ of that observed in guanylate cyclase activity. The $5^{\prime}$-nucleotidase activity of the abdominal testis was $170 \%$ higher than the scrotal testis. This finding contrasts with a 40\% decrease in particulate guanylate cyclase activity seen in the abdominal testis. Thus, the changes in guanylate cyclase activity appears to be independent of the alterations in at least two other representative enzymes.

To gain further insight into which cell types were involved in the changes in cGMP metabolism, an immunocytochemical technique that localizes cGMP was used. Within 10 days after rats were rendered cryptorchid, the predominant cell types remaining within seminiferous tubules of the abdominal testis are spermatogonia, Sertoli's cells, and occasional spermatocytes. Cytologically, interstitial cells appear unaffected by the elevated temperature (25). When the immunocytochemical distribution of cGMP was examined in the scrotal testes of rats 30 days after surgery (Fig. 3), a pattern of cGMP fluorescence was observed that was characteristic of that previously described in testis from adult rats (5). Cyclic GMP was observed in both cytoplasmic and membranous locations. Particularly striking is the distribution on the chromosomes of pachytene spermatocytes and the bright perinuclear cGMP fluorescence associated with elongated nuclei of mature spermatids. Nuclear staining within the nuclei of interstitial cells is also prominent. When the distribution of cGMP was examined in abdominal testis 30 days after surgery, the loss of germinal cells was apparent. A definite enhancement of cGMP fluorescence is seen in the cells lining

TABLE IV

The Effect of Unilateral Cryptorchidism on LDH and 5'-Nucleotidase Activity

\begin{tabular}{lrrc}
\hline & \multicolumn{2}{c}{ Testis } & \\
\cline { 2 - 3 } & \multicolumn{1}{c}{ Scrotal } & Abdominal & Change \\
\hline & & & $\%$ \\
LDH & & & $\% .04 \pm 0.09$ \\
$5^{\prime}$ '-nucleotidase & $5.89 \pm 0.23$ & +180 \\
\hline
\end{tabular}

The activity of a soluble (LDH) and a particulate (5'-nucleotidase) enzyme was determined in the scrotal and abdominal testis from unilateral cryptorchid rats (Methods). The LDH activity is expressed in micromoles substrate converted per milliliter per minute. The $5^{\prime}$-nucleotidase activity is expressed as micromoles product per gram tissue per minute. The values given are the mean of three rats in each group \pm SEM. 
the inner aspect of the seminiferous tubule, the cells of the tubular wall, and cells in the interstitial areas.

\section{DISCUSSION}

The data presented show that surgically induced unilateral cryptorchidism produced a significant elevation in tissue cGMP content and in the measurable activity of soluble guanylate cyclase. The ratio between soluble and untreated particulate guanylate cyclase was profoundly altered changing from 1:1.5 in the adult to 5:1 in the cryptorchid testis. Because the shift in the ratio occurred in 20-and 60-day-old rats, it is logical that the effects take place in the cell types which survive in the abdominal location. The immunocytochemical studies confirm this supposition by demonstrating an increase in cGMP fluorescence in cells in the peritubular areas and in intertubular areas (interstitial cells). Braun et al. (26) have reported that in the normal rat, $<20 \%$ of the total guanylate cyclase activity is present in interstitial cells. However, the present observations indicate that the changes in cGMP metabolism occur in several cell types. Further experimentation will be necessary to assess the magnitude of change in the different cell populations.

The regulation of guanylate cyclase activity appears to be quite complex. The enzyme does not appear to be directly stimulated by hormone receptor complexes as is the particulate adenylate cyclase; rather, the moment to moment activity depends upon the local physiochemical environment (10). A host of activity determinants exist which include cation concentrations, adenine nucleotides, fatty acids, and alterations in oxidation-reduction reactions. With regard to the increase in soluble guanylate cyclase activity in the abdominal testis, the following observations and literature are pertinent. Alterations in lipid metabolism have been reported in the cryptorchid rat testis (27) and could be responsible for the observed changes. However, during the alteration in the activity of human platelet soluble guanylate cyclase by arachidonic acid, kinetic analysis shows that both the $V_{\max }$ and the $K_{m}$ are slightly altered (13). Only the $V_{\max }$ of the abdominal testis enzyme was observed to change during cryptorchidism. Additionally, it is likely that if altered fatty acid content caused the observed results, there would have been some activation of the scrotal activity when the two enzymes were mixed. Further work to determine the effect of fatty acids on the testicular guanylate cyclase will be needed to firmly conclude that they are not involved in the observed changes. An additional point worthy of note is that an increase in activity of the soluble enzyme from certain tissues has been reported due to an oxygen-dependent process (14). However, the testis does not undergo this process of autoactivation. $^{2}$
To unequivocally answer the question of whether the increase in soluble activity is due to the synthesis of new enzyme or the activation of preexisting enzyme, direct measurement of the number of enzyme molecules by an immunochemical assay will be needed. The kinetic data, the mixing experiments, and the points considered above suggest to the authors that the increase in activity is due to an increase in the amount of enzyme. In contrast, during rat liver regeneration particulate guanylate cyclase activity is increased and soluble guanylate cyclase activity is either decreased (3) or unchanged $(2,15)$. The molecular mechanism by which the postulated independent regulation of two enzyme forms occurs is yet to be ascertained. The distinct biochemical properties, different molecular size, variable ratio from tissue to tissue, and independent regulation within the same tissue make it likely that the two enzyme forms are distinct and argues for a mechanism which would allow asynchronous control of the two forms of guanylate cyclase. The differences listed above could be explained by a model in which the two forms of the enzyme are coded for by separate genes. Independent regulation would take place at the level of the genome, i.e., transcription. On the other hand, the presence of a core catalytic unit for both enzyme forms cannot be ruled out. In fact, a previous report (28) demonstrates that when the particulate enzyme from sea urchin sperm is purified to apparent homogeneity, it exhibits the kinetic properties usually attributed to a soluble guanylate cyclase. Therefore, another possible control mechanism might involve the transcription of one gene coding for a common catalytic unit of guanylate cyclase. Subsequent posttranscriptional or posttranslational modification would lead to the preferential partitioning of soluble and particulate forms. However, it should be noted that alternate explanations for the increase in soluble activity exist. These include: an alteration in the turnover time for the two enzymes, or in distribution of guanylate cyclase within the surviving cell types of the cryptorchid testis. The latter is less likely due to the immunocytochemical data and the total increase in soluble guanylate cyclase activity per testis.

Another example of the tissue to tissue diversity of cGMP metabolism is shown by the studies of Craven and DeRubertis (29) that have correlated the tissue concentration of cGMP in different anatomic regions of the rat kidney with the particulate guanylate cyclase activity. Additionally, some tumors have a higher concentration of cGMP than their derived tissue (30); this change is also correlated with an increase in the ratio of the particulate enzyme. The present report demonstrates that a sustained elevation of soluble guanylate cyclase activity is correlated with an increase in testicular cGMP levels.

The physiologic significance of the alteration in 

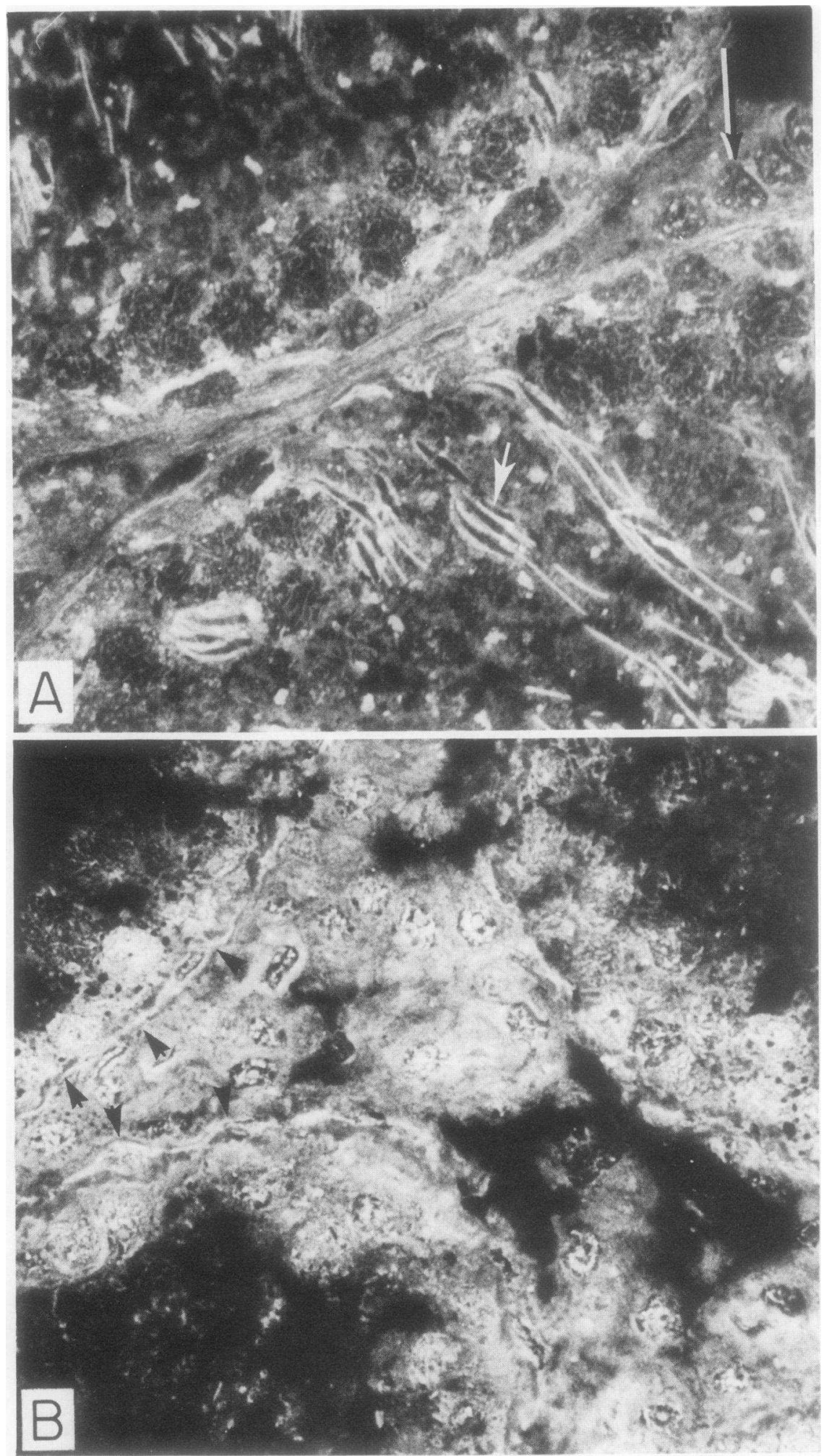
cGMP metabolism in the cryptorchid testis is unknown but several possibilities seem relevant. The major changes appear to be taking place in cells in the peritubular and intertubular areas. Thus, the changes in cGMP metabolism observed appear to be occurring in several different cell types. The cryptorchid testis is a functionally injured organ and these alterations may represent a response to the environmentally induced injury. It is interesting to note, however, that soluble guanylate cyclase activity and cGMP levels are also elevated during early testicular development (31). Early development and cryptorchidism are characterized by an absence of mature germinal elements (i.e., spermatids) within seminiferous tubules. Therefore, it is possible that the level of soluble guanylate cyclase and cGMP are in some way linked by a feedback mechanism during the complex process of spermatogenesis.

\section{ACKNOWLEDGMENTS}

We would like to acknowledge the helpful suggestions of Dr. Brian Setchell, and the excellent assistance of Celeste Layton and Vonnie Stinnett in preparing this manuscript.

This research was supported in part by grants AM19796, AM 17438, and AM05510 from the National Institutes of Arthritis, Metabolism, and Digestive Diseases and a University of North Carolina Research Council Award.

\section{REFERENCES}

1. Goldberg, N. D., and M. K. Haddox. 1977. Cyclic GMP metabolism and involvement in biological regulation. Annu. Rev. Biochem. 46: 823-896.

2. Zeilig, C. E., and N. D. Goldberg. 1977. Cell-cyclerelated changes of $3^{\prime}: 5^{\prime}$-cyclic GMP levels in Novikoff hepatoma cells. Proc. Natl. Acad. Sci. U. S. A. 74: 1052-1056.

3. Koide, Y., S. Earp, S. Ong, and A. Steiner. 1977. Intracellular localization of cyclic GMP and guanylate cyclase activity during rat liver regeneration. Fed. Proc. 36: 347.

4. Kimura, H., and F. Murad. 1975. Increased particulate and decreased soluble guanylate cyclase activity in regenerating liver, fetal liver, and hepatoma. Proc. Natl. Acad. Sci. U. S. A. 72: 1965-1969.

5. Spruill, A., and A. Steiner. 1976. Immunohistochemical localization of cyclic nucleotides during testicular development. J. Cyclic Nucleotide Res. 2: 225-239.
6. Kimura, H., and F. Murad. 1974. Evidence for two different forms of guanylate cyclase in rat heart. J. Biol. Chem. 249: 6910-6916.

7. Chrisman, T. D., D. L. Garbers, M. A. Parks, and J. G. Hardman. 1975. Characterization of particulate and soluble guanylate cyclases from rat lung. J. Biol. Chem. 250: $374-381$.

8. Kimura, H., and F. Murad. 1976. Subcellular localization of guanylate cyclase. Life Sci. 17: 837-844.

9. Goldberg, N. D., R. F. O'Dea, and M. K. Haddox. 1973. Cyclic GMP. Adv. Cyclic Nucleotide Res. 3: 155-233.

10. Kimura, H., and F. Murad. 1975. Two forms of guanylate cyclase in mammalian tissues and possible mechanisms for their regulation. Metab. Clin. Exp. 24: 439-445.

11. Schultz, G., J. F. Hardman, K. Schultz, C. E. Baird, and E. W. Sutherland. 1973. The importance of calcium ions for the regulation of guanosine $3^{\prime}: 5^{\prime}$-cyclic monophosphate levels. Proc. Natl. Acad. Sci. U.S. A. 70: 3889-3893.

12. Wallach, D., and I. Pastan. 1976. Stimulation of guanylate cyclase of fibroblasts by free fatty acids. J. Biol. Chem. 251: 5802-5809.

13. Glass, D. B., W. Frey, D. W. Carr, and N. D. Goldberg. 1977. Stimulation of human platelet guanylate cyclase by fatty acids. J. Biol. Chem. 252: 1279-1285.

14. White, A. A., K. M. Crawford, C. S. Patt, and P. J. Lad. 1976. Activation of soluble guanylate cyclase from rat lung by incubation or by hydrogen peroxide. J. Biol. Chem. 251: 7304-7312.

15. Goridis, C., and W. Reutter. 1975. Plasma membraneassociated increase in guanylate cyclase activity in regenerating rat liver. Nature (Lond.). 257: 698-700.

16. Steiner, A. A., A. S. Pagliara, L. R. Chase, and D. M. Kipnis. 1972. Radioimmunoassay for cyclic nucleotides. II. Adenosine 3',5'-monophosphate and guanosine 3',5'monophosphate in mammalian tissues and body fluids. J. Biol. Chem. 247: 1114-1120.

17. Lowry, O. H., N. J. Rosebrough, A. L. Farr, and R. J. Randall. 1951. Protein measurement with the Folin phenol reagent. J. Biol. Chem. 193: 265-275.

18. Burton, K. 1956. A study of the conditions and mechanisms of the diphenylamine reaction for the colorimetric estimation of deoxyribonucleic acid. Biochem. J. 62: 315-323.

19. Wroblewski, F., and J. S. LaDue. 1955. Lactic Dehydrogenase in blood. Proc. Soc. Exp. Biol. Med. 90: 210-213.

20. Steiner, A. L., S. H. Ong, and J. Wedner. 1976. Cyclic nucleotide immunocytochemistry. Adv. Cyclic Nucleotide Res. 7: 115-155.

21. Van Demark, M. L., and M. J. Free. 1970. The Testis. A. D. Johnson, W. R. Gomes, and M. L. Van Demark, editors. Academic Press, Inc., New York. 3: 233-312.

22. Hagenas, L., and E. M. Ritzen. 1976. Impaired Sertoli

FIGURE 3 Immunocytochemical localization of cyclic GMP in testes of unilaterally cryptorchid rats. Rats were rendered cryptorchid at 60 days of age and sacrificed 30 days postoperatively. Unfixed, frozen sections of testis were prepared, and cyclic GMP was localized immunocytochemically as described in Methods. (A) Cyclic GMP fluorescence in the scrotal testis, 30 days after surgery, is observed within Sertoli's cells, spermatogonia, and cells undergoing meiosis (spermatocytes). Note cGMP fluorescence associated with the chromosomes of pachytene spermatocytes. White arrow within the seminiferous tubule indicates perinuclear cGMP fluorescence associated with mature spermatid nuclei. Interstitial cell nuclei (white/black arrow) also show cGMP fluorescence. (B) Cyclic GMP fluorescence in the abdominal testis, 30 days postoperatively, is markedly enhanced in surviving cells in the peritubular areas of seminiferous tubules. Note loss of cells distal to primary spermatocytes (i.e., spermatids). Arrows indicate the limits of the seminiferous tubules. Cyclic GMP fluorescence within intertubular areas is also enhanced. $(\times 450)$. 
cell function in experimental cryptorchidism in the rat. Mol. Cell. Endocrinol. 4: 25-34.

23. Leblond, C. P., and Y. Clermont. 1952. Definition of the stages of the cycle of the seminiferous epithelium in the rat. Ann. N. Y. Acad. Sci. 55: 548-573.

24. Ford, E., and C. Huggins. 1963. Selective destruction in testis induced by 7,12-dimethylbenz [a] anthracene. J. Exp. Med. 118: 27-40.

25. Leeson, T. S., and C. R. Leeson. 1970. Experimental cryptorchidism in the rat. A light and electron microscope study. Invest. Urol. 8: 127-143.

26. Braun, T., H. Frank, R. Dods, and S. Sepsenwol. 1977. $\mathrm{Mn}^{++}$sensitive, soluble adenylate cyclase in rat testis. Differentiation from other testicular nucleotide cyclases. Biochim. Biophys. Acta. 481: 227-235.

27. Lynch, K. M., and W. W. Scott. 1951. Lipid distribution in the Sertoli cell and Leydig cell of the rat testis as related to experimental alterations of the pituitary gland system. Endocrinology. 49: 8-14.

28. Garbers, D. L. 1976. Sea urchin sperm guanylate cyclase. Purification and loss of co-operativity. J. Biol. Chem. 251: 4071-4077.

29. Craven, P. A., and F. F. DeRubertis. 1976. Properties and subcellular distribution of guanylate cyclase activity in rat renal medulla: correlation with tissue content of guanosine 3',5'-monophosphate. Biochemistry. 15: 51315137.

30. Criss, W. E., F. Murad, and H. Kimura. 1976. Properties of guanylate cyclase from rat kidney cortex and transplantable kidney tumors. J. Cyclic Nucleotide Res. 2: 11-19.

31. Spruill, W. A., A. L. Steiner, and H. S. Earp. 1977. Testicular guanylate: correlation between tissue cGMP levels and soluble guanylate cyclase activity. Fed. Proc. 36: 347. 